\title{
WILLING LANDLORDS, UNRESPONSIVE BUSINESS TENANTS
}

\author{
Rosemary Carson, Partner, Carson McDowell, Solicitors and \\ Norma Dawson, Professor of Law, Queen's University Belfast.
}

When the Law Reform Advisory Committee for Northern Ireland embarked upon its First Programme for Law Reform in 1990, one of the topics included in the programme was the law of business tenancies as enacted in the Business Tenancies Act (Northern Ireland) 1964. The 1964 Act was broadly equivalent to its English counterpart, the Landlord and Tenant Act 1954, Part II, but unlike the 1954 Act, it had not been significantly amended in light of difficulties which had arisen in the operation of the legislation. The Committee published a Discussion Paper in $1992^{1}$ and, after a consultation period, this was followed by a Report on Business Tenancies (the "LRAC Report") in 1994.2 The Report contained a draft Order which has been substantially adopted as the text of the Business Tenancies (Northern Ireland) Order 1996. ${ }^{3}$ In the 1994 Report, the Committee explained its approach to reform of the law of business tenancies:

"We confirm our view that the main substance of the [1964] Act should be retained but with a number of amendments. These amendments are not aimed at changing the fundamental principles of the legislation but will, we hope, have the effect of streamlining its operation. Our objective has been to maintain a fair balance between the parties to a tenancy in a context of legal certainty and simplicity. ... . We are also of the view that any interference with the initial contract between a landlord and tenant should be kept to a minimum."

The Order created gains and corresponding losses for both landlords and tenants. In the interests of tenants, the Committee firmly rejected the possibility of contracting out of the protection of the Order, even though this is an established feature of the English system. ${ }^{5}$ The Order does, however, allow for agreements to surrender sanctioned by the Lands Tribunal, ${ }^{6}$ and it extends the term of short lettings that may be granted without the tenant obtaining security of tenure. ${ }^{7}$ The Tribunal now has the power to vary the rent during interim continuation and to backdate the revised rent under the new tenancy. ${ }^{8}$ Further, landlords have been given a right in certain

1 Discussion Paper No 3: A Review of the Law relating to Business Tenancies in Northern Ireland (HMSO, 1992).

2 Business Tenancies, LRAC No 2, (HMSO, 1994).

3 SI 1996/725 (NI 5), repealing and replacing the Business Tenancies Act (NI) 1964. Hereafter, "the 1996 Order".

4 Op cit, $\mathrm{n} 2$ above, paras 1.7 and 2.1.

5 Ibid, para 3.5.9.

6 Art 25, 1996 Order.

7 Art 4(1)(a), 1996 Order.

8 Arts 11(3) and 18(3), 1996 Order. 
circumstances to make a tenancy application. ${ }^{9}$ The position of tenants, on the other hand, has been strengthened in line with the Committee's proposals in a number of ways. Several procedural changes benefit tenants, as explained below. The ground of opposition to renewal most commonly relied on, paragraph (f), has been significantly strengthened to prevent landlords recovering possession on slight or unfounded pretexts. ${ }^{10}$ The provision for compensation for disturbance has also been enhanced. Compensation levels have been increased and compensation is now more widely available. ${ }^{11}$ Other changes made by the Order, notably the Tribunal's power to alter time limits, have the potential to benefit either party. ${ }^{12}$ The purpose of this paper is to consider some of the procedural changes made by the Order and to assess whether they do in practice achieve the Committee's objective of creating and maintaining momentum and certainty in the renewal process.

The streamlining of the procedures for commercial lease renewal under the Order incorporated a number of features designed to ensure that the renewal process retains momentum and that neither party loses substantive rights on a "mere technicality"13 or is prejudiced as a result of any inertia on the part of the other. The removal of some of the more onerous aspects of the 1964 Act, such as the obligation on the part of a tenant upon receipt of a landlord's notice to determine, to serve not one but two notices to safeguard his position, ${ }^{14}$ has simplified the process and should therefore be welcomed. The changes in the 1996 Order were, however, predicated on the assumption that both parties would embrace the new streamlined approach and co-operate with each other in the renewal process. ${ }^{15}$ Unfortunately, this assumption is not always borne out in practice and many of the changes designed to enhance and expedite the renewal process can, in fact, frustrate and prolong it. This is particularly the case where there is a willing landlord and an unresponsive tenant. In the converse case where the tenant seeks renewal but the landlord does not respond, the Order enables the tenant to force the pace, by making a tenancy application.

When the renewal procedure is triggered by a landlord willing to grant a new tenancy, the Order provides for an "upfront" approach in that the landlord's notice to determine must state the general terms of his proposals for the new tenancy, including rent, duration and the property to be comprised in the new tenancy. ${ }^{16}$ This ensures that the tenant has information which is relevant to the decisions to be taken in response to the landlord's notice. A further procedural change is that the tenant is no longer required to serve a counternotice following receipt of the landlord's notice to determine. The thinking

9 Art 10(1)(a), 1996 Order.

10 Arts 12(1)(f) and 13, 1996 Order.

11 Art 23, 1996 Order.

12 Art 10(5), 1996 Order.

13 Op cit, $\mathrm{n} 2$ above, para 4.4.7.

$14 \mathrm{~S} 4(6)(a)$ (tenant's counter-notice) and s 8 (tenant's application for a new tenancy) of the 1964 Act.

15 Op cit, n 2 above, para 4.4.5.

16 Art 6(6)(a), 1996 Order. Under s 4 of the 1964 Act, the landlord merely indicated whether or not he was willing to renew: see Dawson, Business Tenancies in Northern Ireland (1994), pp 82-94. 
behind this reform, as explained in the LRAC Report, was that, following receipt of a notice to determine served by an unwilling landlord, the parties might as well proceed directly to a tenancy application, whilst on receipt of a notice to determine served by a willing landlord, the parties will enter into negotiations as to the terms of the new tenancy. ${ }^{17}$ If a tenant was aware of the landlord's proposals for a new tenancy from the outset, this would presumably encourage such negotiation which in turn would lead to the grant of a new tenancy without the need for a tenancy application ${ }^{18}$ or, if unsuccessful, would lead to the matter being brought before the Lands Tribunal by virtue of a tenancy application.

A further change contemplated by the Committee but rejected, would have enabled the parties to make a tenancy application up to 12 months from the expiry of the "date of termination" specified in a landlord's article 6 notice to determine, or the "date of commencement" detailed in a tenant's article 7 request for a new tenancy. Whilst this would have facilitated a longer process of negotiation, the Committee ultimately decided that it would be an unacceptable breach of the fundamental philosophy of the 1964 Act which was to ensure that an application to the Tribunal was made, if possible, before the end of the contractual term. ${ }^{19}$ The Order therefore requires any tenancy application to be made before the date of termination/commencement. ${ }^{20}$ This provision in itself can prolong the renewal process. The landlord's notice to determine or tenant's request for a new tenancy can specify a date of determination/commencement as far as one year in advance. ${ }^{21}$ Under the 1996 Order, this specified date is the deadline for making a tenancy application, whereas under the 1964 Act, a tenancy application had to be made not less than 2 nor more than 4 months after the service of the landlord's notice to determine or the landlord's response to a tenant's request for a new tenancy. The practical effect of the changes introduced by the Order is that up to a year could elapse between the service of a notice by a willing landlord and the making of tenancy application by the tenant, causing additional delay and uncertainty for the landlord.

In connection with tenancy applications, the Lands Tribunal has been given two important new powers. The first of these is a power to vary, by extension or reduction, the time limits within which the tenancy application must be made..$^{22}$ This was principally in order to ensure that, if negotiations break down after the date for termination/commencement specified in an article 6 notice or article 7 request, the parties' rights are not lost in the process. ${ }^{23}$ Formerly, if time limits were not complied with, a party lost the right to apply to the Lands Tribunal, but by adopting this new paternalistic approach, the Order gives the Tribunal discretion to "bend the rules" if it considers it appropriate to do so. This power has already been exercised by the Lands Tribunal in the case of $J$ L Harvey v Schofield \& Anderson

17 Op cit, n 2 above, para 4.4.5.

18 See art 10, 1996 Order.

19 Op cit, n 2 above, para 4.4.6.

20 Art 10(2) and (3) 1996 Order.

21 Arts 6(2) and 7(2) 1996 Order.

22 Art 10(5) 1996 Order.

23 Op cit, n 2 above, para 4.4.7. 
Limited. ${ }^{24}$ In this case, the parties had been negotiating a new tenancy and time had simply "run out". When the tenant applied for an extension of the time limit for making a tenancy application, the Lands Tribunal granted an extension in light of the "complete loss of property rights if the application were refused". Significantly, the Tribunal went on to emphasise that its discretion was not confined to situations in which "somebody was a day or so out of time". With respect to the principles behind its decision-making, it declared that "it is perhaps appropriate to begin with something close to a clean sheet and for principles to evolve from decisions case by case".

The second power conferred on the Tribunal under the 1996 Order is a power to vary the rent payable during interim continuation of tenancies which are the subject of a pending tenancy application. ${ }^{25}$ This innovation brings to an end the financial interest which tenants formerly had in protracted delays in the process and is likely to lead to a reduction in pre-emptive strikes, whereby a tenant rushed to serve a request for a new tenancy specifying a date of commencement as far in advance as possible. ${ }^{26}$

A further procedural change made by the Order, and the source of the problem discussed in this paper, is that either party may now make a "tenancy application", which means, however, either an application by the landlord for an order that the tenant is not entitled to a new tenancy, or an application by the tenant for an order for the grant of a new tenancy. ${ }^{27} \mathrm{~A}$ difficulty arises under the Order when a tenant receives a notice to determine (or a response to a request for a new tenancy, pursuant to article 7(6)(a) of the Order) from a landlord willing to renew, and makes no response at all. The landlord, having already indicated his willingness to renew, is precluded from making a tenancy application in order to bring matters to a head, because as we have just seen, an application can only be made by a landlord for an order that the tenant is not entitled to a new tenancy. Further, the combined effect of articles 10(1) and 12(1) is to allow the landlord to make a tenancy application only on the grounds of opposition to renewal stated in the landlord's notice to determine or, as the case may be, in the landlord's response to the tenant's request for a new tenancy. A willing landlord by definition will have no grounds for making a tenancy application and, if faced with an unresponsive tenant, is left in limbo without any mechanism to resolve the matter.

It seems unlikely that a landlord's willingness to renew was anticipated as a fresh source of stalemate under the 1996 Order. On the contrary, enabling either party to apply to the Tribunal was intended to maintain momentum. Although some sections of the LRAC Report suggest that landlords might make a tenancy application either for the refusal or grant of a new tenancy, ${ }^{28}$ the draft Order appended to the Report is in substantially the same terms as the Order as enacted and it is fairly clear that these provisions were intended to provide a complete answer to the problems encountered under the earlier

BT/27/1998.

5 Art 11(3) and (4), 1996 Order.

26 See Dawson, op cit, n 16 above, p 98.

27 Art 10(1), 1996 Order.

28 Op cit, $\mathrm{n} 2$ above, para 4.4.10, second bullet point; paras 4.4 .5 and 4.4 .6 are more ambiguous. 
law. One proposal made by the Committee and incorporated in the draft Order, which was abandoned at a later stage in the legislative process, sheds some light on the matter. The Committee proposed that a landlord who had initially opposed renewal might subsequently concede a willingness to renew in order to enable him to apply to the Lands Tribunal for an order for the grant of a new tenancy. ${ }^{29}$ This is the only example of the landlord being seen as requiring a power to apply for an order for the grant, rather than refusal, of a tenancy. Apart from this exceptional proposal, which was not finally enacted, the Order seems to be based upon an assumption that landlords do not need power to apply to the Tribunal except in the circumstances set out in article 10(1). In consequence, the legislation does not provide a clear solution for the situation where a tenant does not respond to a willing landlord's proposals by beginning negotiations with all due expedition, yet in practice, willing landlords are often met with a lack of response from the tenant. Whether this unresponsiveness is due to apathy or a deliberate desire to block or prolong the renewal process, the result is the same - uncertainty for all parties.

A landlord's notice to determine specifies a date of determination and a tenant's request for a new tenancy specifies a proposed date of commencement of a new tenancy. The consequence is that, in the problem scenario, the old tenancy will terminate on the date of termination or immediately prior to the proposed date of commencement, as the case may be, in accordance with article 5 of the Order. There is ample authority to support this proposition, for example, Meah $\mathrm{v}$ Sector Properties Limited. ${ }^{30}$ The discretionary power given to the Lands Tribunal by virtue of article 10(5)(a) appears, however, to give it the ability to resurrect determined tenancies ${ }^{31}$ and it would seem that if a landlord has received no response to his statement of willingness by the date of termination/commencement specified in the relevant article 6 notice or article 7 request, and notwithstanding that no tenancy application has been made by such date, he can no longer take it for granted that the existing tenancy is at an end or that he is free to utilise or dispose of the premises. Unfortunately, there is no clear guidance either in the legislation itself or in the case law to date as to when an application to extend the article 10 time limits would be granted or refused. At the very least, the impact of the Human Rights Act 1998 and the landlord's right to the enjoyment of his property would seem to be relevant considerations in the exercise of the discretion. ${ }^{32}$

29 Ibid, para 4.4.9 and art 10(6) of the draft Order contained in Appendix A of the Report.

30 [1974] 1 All ER 1027. See Dawson, op cit, n 16 above, p 93. For a recent example, see London Baggage Co (Charing Cross) Ltd v Railtrack plc, unreported, 17 April 2000.

31 As noted earlier, art 11 of the 1996 Order will not apply where the tenancy has been terminated by a landlord's notice or tenant's request and no tenancy application has been made.

32 More specifically, art 1 of Protocol 1 to the European Convention on Human Rights provides that "[e]very natural or legal person is entitled to the peaceful enjoyment of his possessions. No one shall be deprived of his possessions except in the public interest and subject to the conditions provided for by law. ..." At what point does the Tribunal's discretion to extend time limits become an unreasonable interference with the landlord's right of property? 
The situation is further complicated if the tenant remains in occupation after the tenancy ends. This overholding cannot be attributed to a continuation tenancy under article 5 of the Order as the statutory continuation mechanism is expressly ousted by the service of a valid landlord's notice (or tenant's request). The tenant's status must, therefore, be analysed in light of general principles of land law. If the tenant remains in occupation and either does not pay rent or offers rent that is refused by the landlord, one can assume that his occupation is by virtue of a tenancy at will or, once possession is demanded, at sufferance to which the Order does not apply. ${ }^{33}$ The landlord could seek to recover possession of the premises by ejectment proceedings (including a claim for mesne profits), but this is clearly an unsatisfactory conclusion to a process which was initiated months earlier by the landlord indicating a willingness to renew the tenancy and specifying actual proposals for renewal. In this instance, the tenant's lack of response and the landlord's inability to progress the matter by bringing it before the Lands Tribunal results in much wasted time and energy which could have been more profitably employed by the landlord actively negotiating a new tenancy with the existing tenant or looking for a new tenant.

The majority of commercial landlords are unlikely to permit occupation of their premises without the receipt of rent in return - even if acceptance of rent may not be the most advisable route to follow in every case. The ongoing payment of rent by the tenant and its acceptance by the landlord in the scenario outlined above can, however, lead to a very uncertain situation. If one accepts that the old tenancy has been determined by the notice to determine or request for a new tenancy, the question arises which type of tenancy arises by virtue of continued occupation and payment of rent. Under general principles of land law, a periodic tenancy can arise by implication in such circumstances. ${ }^{34}$ The type of periodic tenancy depends on how the rent accepted by the landlord is calculated rather than how it is paid. Most commercial rents are assessed on an annual basis. If this is the case in the problem scenario, and the existing rent continues to be paid, a yearly periodic tenancy could be said to have arisen. Such periodic tenancies continue indefinitely until terminated and are protected by the provisions of the 1996 Order, so in this situation the landlord is faced with having to initiate the whole renewal process all over again. It could, however, be argued that an implied periodic tenancy should not be inferred from payment of rent, where the landlord accepted it as a payment against liability for mesne profits in respect of the tenant's overholding as a mere tenant at will. ${ }^{35}$ Nevertheless, where the landlord has already indicated a willingness to renew, and continues to accept the same rent after the determination of the old tenancy, the inference of a periodic tenancy is compelling. ${ }^{36}$

33 Art 2(2), 1996 Order.

34 See Dawson, op cit, $\mathrm{n} 16$ above, pp 13-4.

35 Longrigg Burrough \& Trounson v Smith (1979) 251 EG 847, Javad v Aqil [1991] 1 All ER 243, and London Baggage, op cit, n 30 above. See also Stirling v Leadenhall Residential 2 Ltd [2001] 3 All ER 645.

36 In the English case, London Baggage, op cit, n 30 above, the court ruled that a periodic tenancy did not arise on the facts when a business tenant continued in possession after the date of termination. The landlord had served a notice to determine and the tenant had not responded. The main reason for the decision was 
The concept of a new periodic tenancy arising from receipt of rent from a tenant who holds over also begs the question, what are the terms of such a tenancy? In the case of the Earl of Meath v Megan, ${ }^{37}$ Gibbon LJ stated:

" where any tenant holds under a lease or agreement in writing, for a term which comes to an end, and he continues in possession without making any fresh agreement, there is a presumption that all the terms of the agreement continue to apply, except so far as they are rendered inapplicable by the changes of the tenancy."

Such authority would seem to prevent a landlord claiming that the terms of a new periodic tenancy should be as proposed in his notice to determine on the basis that the tenant has impliedly accepted these by remaining in possession. In simple terms, this means that a landlord willing to renew on fresh terms can be faced with a new periodic tenancy at the old rent, due to the tenant's lack of response. This is patently unfair, particularly in a buoyant market. The new power given to the Lands Tribunal by virtue of article 11(3) to vary the rent in a continuing tenancy was specifically designed to protect a landlord's interests in the event of a continuing tenancy, particularly if a tenant was deliberately prolonging the process. It is therefore ironic that, in this problem scenario, where a tenant's unresponsiveness has caused the ultimate delay and prevented the continuation of the old tenancy, this mechanism is unavailable. Article 11(3) specifically provides that the power can be invoked "where the term of a tenancy is extended in consequence of the operation of paragraph (1)". Article 11(1) in turn only comes into play when an existing tenancy is continued by virtue of a tenancy application having been made.

Matters become more complicated where the landlord demands a different rent as specified in his initial notice to determine and the tenant remains in possession paying this revised rent. In these circumstances, it is not clear whether a periodic tenancy on the same terms as the old lease has arisen, albeit at a varied rent, or whether the payment of the revised rent is also evidence of the tenant's acceptance of any other different terms specified in the landlord's notice. In such a situation, an inventive landlord could also argue that something more than a periodic tenancy has arisen. Section 4 of the Landlord and Tenant Law Amendment Act (Ireland) 1860 ("Deasy's Act") provides that:

"every lease or contract with respect to lands whereby the relation of landlord and tenant is intended to be created for any freehold estate or interest, or for any definite period of time not being from year to year or any lesser period, shall be by deed

that the landlord had indicated in its notice its opposition to renewal. What is argued here is that the converse may also be true; where the landlord indicates a willingness to renew, the tenant does not respond, the tenancy comes to an end, and the tenant continues in possession paying the old rent, which the landlord accepts, it is difficult for the landlord to argue that a periodic tenancy has not arisen by implication.

37 [1897] 2 IR 477; 31 ILTR 93. 
executed, or note in writing signed by the landlord or his agent thereunto lawfully authorised in writing."

The setting out of proposals for a new tenancy in writing by the landlord in the notice to determine (or response to the tenant's request for a new tenancy) could not easily be seen as a grant of a new tenancy as such proposals are made during the continuance of the old tenancy. It is, however, possible to argue that such proposals constitute an offer. Case law supports the view that such an offer can be impliedly accepted by conduct, and that if, following receipt of the offer, the tenant remains in possession, it becomes arguable that a contract has been concluded. ${ }^{38}$ In a Scottish case, M'Farlane v Mitchell, ${ }^{39}$ a landlord wrote to the tenant of a shop, not giving notice to quit but proposing new terms for continued occupation. The tenant stated that the terms were unacceptable. The landlord wrote to him again, insisting that the earlier letter contained the terms on which the tenant could continue in occupation in the coming year. The tenant made no response but remained in possession. The Court of Session held that the tenant was bound to pay the higher rent which the landlord had proposed. Lord Moncrieff asked: "What is the proper inference? I think that the reasonable inference is that he agreed to the landlord's terms, and that he is now bound by them." 40 There is no rule of law, however, that a tenant who continues in possession following an offer of a new tenancy is deemed to have accepted it; this conclusion depends on the facts of each case. ${ }^{41}$ Such an inference could only arise in the case under consideration if the tenant continues in occupation after the old tenancy has been brought to an end as a result of the landlord's notice.

If it can be established that an agreement for a lease has been concluded, then since equity regards as done what ought to be done, the agreement for a lease is as good as a lease itself, under the rule in Walsh $\mathrm{v}$ Lonsdale. ${ }^{42}$ The landlord might seek to enforce such an agreement by decree of specific performance, which for this purpose would have to comply with the formalities required for contracts set out in the Statute of Frauds (Ireland) Act 1695, that is, the agreement must be evidenced by a note or memorandum in writing, signed by the party to be charged or his authorised agent. $^{43}$ In our scenario, such formalities are not met because there is no signature by the tenant who is the party "to be charged" (that is, the defendant in the action to enforce the contract for a lease). Nevertheless, an agreement for a lease is still specifically enforceable in equity if there are sufficient acts of part performance of the contract for a lease to take the case outside the Statute of Frauds. These acts must be performed by the plaintiff in the potential action, that is, the landlord in the case under consideration. In our scenario, following the failure of the tenant to challenge the landlord's

38 Chitty on Contracts (27 $7^{\text {th }}$ ed, 1994), vol 1, para 2.018, and Roberts v Harwood (1828) 3 C \& P 432.

39 (1900) 2 F 901.

40 Ibid, p 904.

41 Glossop v Ashley [1921] 2 KB 451.

42 (1882) 21 Ch D 9. And see Sheridan, "Walsh v Lonsdale in Ireland" (1952) 9 NILQ 190, and Wylie, Irish Land Law (3 $\left.{ }^{\text {rd }} \mathrm{ed}, 1997\right)$, para 3.038.

43 See Wylie, Irish Conveyancing Law (1978), chp 9. 
proposals and his continuance in possession paying a revised rent, ${ }^{44}$ the landlord's receipt of that rent can be relied on as a sufficient act of part performance, clearing the way for a decree of specific performance of the agreement for a lease. Such an argument is supported by both $\operatorname{Irish}^{45}$ and English $^{46}$ authority. In Conner v Fitzgerald, for example, lands in Co. Cork were let for 21 years until 1872. When the lease expired, the parties entered into a verbal agreement for a new lease for 31 years. The tenant paid the increased rent for a while but subsequently claimed to be a periodic tenant from year to year. The catalyst for the tenant's actions - and a relevant factor in a number of other cases decided in the Irish courts in the 1880s, involving this issue - was the enactment of the Land Law (Ireland) Act 1881, which conferred new rights on yearly tenants. The tenant in Conner hoped to take advantage of his alleged status as yearly tenant to secure a reduced rent under the 1881 Act. Following earlier English and Irish authority, Chatterton V-C granted the landlord a decree of specific performance of the agreement for a 31-year lease, stating that:

\begin{abstract}
"The payment of an increased rent per se is not sufficient proof of part performance, but if there is evidence to show that it was paid by the tenant and accepted by the landlord on foot of the new tenancy, there is, in my opinion, sufficient part performance." 47
\end{abstract}

Rejecting counsel's argument that payment of rent is a sufficient act of part performance by the tenant only, he considered that "there was a corresponding part performance by the landlord in accepting the rent, and permitting the tenant to continue in possession." 48

In the English case of Miller \& Aldworth Ltd v Sharp, the tenants of "The Jolly Millers", an inn at Dartford, Kent, verbally agreed with the landlords for a new lease for 21 years at an increased rent. No lease was executed. Three years later, the landlords, realising that the rent agreed was considerably lower than that justified by current market conditions, refused to honour the arrangement. The case was eventually compromised, after the court ruled that there were sufficient acts of part performance by the

44 Where the tenant stays on paying the old rent, this does not constitute an act of part performance: Sweeney v Denis (1883) 17 ILTR 76.

45 Archbold v Lord Howth (1866) IR 1 CL 608, Howe v Hall (1870) IR 4 Eq 242, Conner v Fitzgerald (1883) 11 LR Ir 106, Beauclerk v Hanna (1888) 23 LR Ir 144, Haire-Foster v McIntee (1888) 23 LR Ir 529. See also McFarlane v Dunne (1890) 24 ILTR 17. This line of authority flourished even though, in the context of purchases of land, a rule had developed in the nineteenth century to the effect that payment of money alone is not a sufficient act of part performance: Clinan v Cooke (1802) 1 Sch \& Lef 22. In the leading contemporary English case on the subject, Steadman v Steadman [1976] AC 536, the House of Lords did not accept this as a general rule and Lords Reid, Simon and Salmon specifically stated that there was no such rule. According to Lord Reid, such a rule "would seem...to defeat the whole purpose of the doctrine" (ibid, p 541). See generally, Wylie, op cit, $\mathrm{n} 43$ above, para 9.059 .

46 Nunn v Fabian (1865) LR 1 Ch 35, Miller \& Aldworth Ltd v Sharp [1899] 1 Ch 622. See also Spry, Equitable Remedies ( $3^{\text {rd }}$ ed, 1984), pp 263, 268 and 275, and Jones and Goodhart, Specific Performance (1986), p 103.

47 Op cit, $\mathrm{n} 45$ above, $\mathrm{p} 113$.

48 Ibid, p 116. 
plaintiffs (in this case, the tenants) to take the case out of the scope of the Statute of Frauds. Interestingly, in this case, the only documentary evidence available was an initial proposal from the landlords for a new lease, and a series of receipts for the increased rent. Byrne J stated:

"In the present case what was done could not refer to the old tenancy, but is in my judgment an unequivocal act referable to some new contract, and that could only be a contract of tenancy. Evidence must, therefore, be admitted to show what the contract was." 49

Thus, the case law establishes that payment and receipt of a revised rent, on foot of a new tenancy, can constitute sufficient acts of part performance to enable either the tenant or the landlord to obtain a decree of specific performance of an agreement for a lease. It is, of course, essential that the plaintiff can prove that an agreement for a new lease was concluded. If the landlord has submitted proposals for the new tenancy and the tenant, not having disputed these, has paid the new rent when demanded, it is at least arguable that an agreement for a lease has been concluded and that it should be specifically enforced.

To summarise, the changes enshrined in the 1996 Order have inadvertently left willing landlords vulnerable to the threat of unresponsive tenants. First, a willing landlord has no ability to initiate a tenancy application and if the formal time limits for the tenant to initiate such an application expire, there is no certainty that the old tenancy has in fact come to an end, because of the Tribunal's new power to extend the time-limits by virtue of article 10(5). Secondly, if a tenant remains in occupation at the determination of a tenancy and a landlord continues to accept rent, a new periodic tenancy could be said to arise. As the tenancy is new rather than "continuing", the Tribunal has no power to increase the rent payable thereunder pursuant to article 11(3). In order to vary the rent or effect other changes, a landlord will be forced to initiate the renewal procedure laid down by the Order all over again. As mooted above, if, following receipt of the landlord's notice to determine or his response to the tenant's request for a new tenancy, the tenant stays on in occupation paying a revised rent as demanded, the landlord might seek a decree of specific performance, arguing that his proposals for a new tenancy were the basis of an agreement for a lease. The outcome of such an action is by no means certain given the discretionary nature of the remedy of specific performance, although case law does tend to support the landlord in this regard, assuming that he can establish actual agreement. The net result of the changes in the not uncommon circumstances under consideration is increased uncertainty in the renewal process which is disappointing and somewhat surprising given Judge Gibson's pronouncement in Joyland Amusements (NI) Limited $v$ AS \& D Enterprises Limited" that "in the field of commercial law certainty is, in the Tribunal's view, of fundamental importance".

The uncertainty also begs the questions, how should it be resolved and, pending resolution, how can willing landlords and their professional advisors mitigate the impact of unresponsive tenants? A simple means of resolving

49 Op cit, $\mathrm{n} 46$ above, p 626.

50 BT/102/1989. 
the particular problem would be to amend article 10(1)(a) to permit willing landlords to initiate a tenancy application seeking an order for the grant of a new tenancy. In the absence of such an amendment, it is advisable for a willing landlord to encourage communication and negotiation with the tenant with a view to settling the terms of a new tenancy prior to the date of termination/commencement specified in the initial trigger notice. It has come to the writers' notice that some landlords in this jurisdiction are seeking to avoid the problems outlined above by serving a notice to determine stating that they will oppose a new tenancy, even if they are willing to grant one. This tends to have the effect of encouraging a response from the tenant. It would, however, be unfortunate if such action were to become common practice, as it is totally at odds with the spirit of the legislation. It could also have adverse implications for a landlord who relied on one of the compensatory grounds of opposition, should the tenant decide to vacate the premises and receive the statutory compensation, rather than pursue a new lease. Another option, if a landlord fears that a tenant is not going to respond as envisaged by the Order, might be for the landlord to make an application under article 10(5) for the Tribunal to reduce the time limit for the making of a tenancy application. This could focus an unresponsive tenant's mind on the renewal process and possibly encourage an early response. Landlords and their professional advisers should also be aware of the implications of continuing to accept rent from a tenant in possession once the date of termination/commencement has passed. In such circumstances, an action for ejectment may be a preferable option even if a landlord would happily grant a new tenancy to the existing tenant.

The business tenancies code has often been described as a "balancing act" between the interests of landlords and tenants. In failing to anticipate the implications for the landlord of an apathetic or mischievous tenant, the 1996 Order appears to have inadvertently tipped the scales in favour of such a tenant. An urgent need exists for equilibrium to be restored by an appropriate statutory amendment or by case law decisively addressing the problem of the unresponsive tenant. 